\title{
Population recovery and differential heat shock protein expression for the corals Agaricia agaricites and $\boldsymbol{A}$. tenuifolia in Belize
}

\author{
Martha L. Robbart ${ }^{1,3}$, Paulette Peckol ${ }^{1, *}$, Stylianos P. Scordilis $^{1}$, H. Allen Curran ${ }^{2}$, \\ Jocelyn Brown-Saracino ${ }^{1}$
}

${ }^{1}$ Department of Biological Sciences, and ${ }^{2}$ Department of Geology, Smith College, Northampton, Massachusetts 01063, USA ${ }^{3}$ PBS\&J Environmental Services, 2001 Northwest 107th Avenue, Miami, Florida 33172, USA

\begin{abstract}
Over recent decades, coral reefs worldwide have experienced severe sea-surface temperature (SST) anomalies. Associated with an El Niño-Southern Oscillation (ENSO) event of 1997-1998, nearly 100\% mortality of the space-dominant coral Agaricia tenuifolia was reported at several shelf lagoonal sites of the Belize barrier reef system; a less abundant congener, A. agaricites, had lower mortality rates. We assessed $A$. agaricites and $A$. tenuifolia populations at coral reef ridges in the south-central sector of the Belize shelf lagoon and forereef sites to document recovery following the 1998 ENSO event and subsequent passage of Hurricane Mitch. To investigate the difference in heat stress tolerance between the 2 species, heat shock protein (HSP) expression was examined in the laboratory under ambient $\left(28^{\circ} \mathrm{C}\right)$ and elevated $\left(+6^{\circ} \mathrm{C}\right)$ temperatures. Populations of A. agaricites and $A$. tenuifolia surveyed at forereef sites in 1999 showed after effects from the 2 disturbances (partial colony mortality was $\sim 23$ and $30 \%$ for A. agaricites and A. tenuifolia, respectively), but partial mortality declined by 2001 . At reef ridge sites, $A$. tenuifolia exhibited 75 to $95 \%$ partial colony mortality in 1999 compared to $18 \%$ in the less abundant A. agaricites. We measured a significant increase in percentage live cover at ridge sites for both Agaricia species from 1999 to 2001, except at Tunicate Ridge; at this site, which has restricted water flow, live $A$. tenuifolia cover remained low $(\sim 10 \%) 3.5 \mathrm{yr}$ after the 1998 warming event, due in part to high sponge cover (>75\%). Immunoblotting results indicated that $A$. agaricites had twice as much HSC $70\left(16.9 \mu \mathrm{g} \mathrm{cm}^{-2}\right)$ as A. tenuifolia $\left(8.7 \mu \mathrm{g} \mathrm{cm}^{-2}\right)$ at ambient temperatures and $6 \times$ as much under the $+6^{\circ} \mathrm{C}$ treatment. In addition to the inducible response by $A$. agaricites, this species expressed HSP 90, whereas $A$. tenuifolia did not. The distinctive patterns of population recovery and HSP expression suggest that $A$. tenuifolia has a lesser ability to produce HSPs for protection against environmental stress than A. agaricites. Such differences in resilience to large-scale environmental disturbances such as intermittent ENSO episodes may drive a dramatic change in coral species abundance patterns.
\end{abstract}

KEY WORDS: Agaricia $\cdot$ Coral reefs $\cdot$ ENSO episodes $\cdot$ Heat shock proteins $\cdot$ Population dynamics Resale or republication not permitted without written consent of the publisher

\section{INTRODUCTION}

Most reef-building scleractinian corals live near their upper thermal limits and may experience heat stress with an increase of only a few degrees centigrade (Jokiel \& Coles 1977, Fitt et al. 2001). Widespread coral bleaching has been associated with thermal anomalies that occur with elevated sea-surface temperatures (SST) accompanying El Niño-Southern Oscillation (ENSO) events (Brown 1997, Wilkinson 2000). Bleaching also has been induced in laboratory heat shock experiments (Hayes \& King 1995). Long-term studies of coral reefs affected by thermal anomalies with resultant coral mortality have revealed that recovery may take several decades (Glynn 1993, Eakin 1996).

Environmental stresses, such as increase or decrease in temperature or salinity, or exposure to heavy metals may deleteriously affect normal metabolic functioning at the cellular level. Proteins that are critical to the maintenance of cell function may become denatured as a result of prolonged or severe environmental stress. For example, heat stress may cause a breakdown of 
enzymatic pathways with consequent biochemical and metabolic dysfunction (Cossins \& Bowler 1987); effects from such a stressor may be exacerbated by influences from other environmental factors (i.e. irradiance, salinity, circulation) (Fitt et al. 2001).

Often, such environmental challenges elicit a cellular response to protect an organism from permanent damage that may result from exposure to these extreme conditions (Craig 1985, Welch 1992). In response to thermal anomalies or UV radiation, Lesser et al. (1990) demonstrated increased activities of enzymes responsible for detoxifying active forms of oxygen in symbionts of the zoanthid Palythoa caribaeorum. Similarly, heat shock proteins (HSPs) serve a protective or reparative function and directly reduce the accumulation of denatured proteins caused by significant environmental change, including heat stress, heavy metals and other metabolic poisons (Craig 1985, Welch 1992, Sharp et al. 1997). Once exposed to non-lethal stress that elicits a response, namely, increased synthesis of HSPs, organisms often show a greater resistance to future, similar environmental disturbances. HSPs are thus vital to organisms in variable environments and are responsible for acclimation at the cellular level (Lindquist \& Craig 1988, Laszlo 1992, Welch 1992).

The cosmopolitan distribution of HSPs across widely disparate taxa led researchers to focus on the role of these proteins in the physiological responses of scleractinian corals to thermal stress. Several HSPs have been documented in coral species, including constitutive (cognate) heat shock protein 70 (HSC 70), and inducible HSP 70, HSP 60 and HSP 25, under heat and UV radiation stress (Hayes \& King 1995, Fang et al. 1997, Sharp et al. 1997, Branton et al. 1999, Downs et al. 2000). HSP 70 is the best-documented heat shock protein, largely because it is highly inducible. For example, field transplant experiments with the Pacific coral Goniopora djiboutiensis demonstrated elevated levels of HSC/HSP 70 following heat shock (Sharp et al. 1997).

However, many studies identifying a $70 \mathrm{kDa}$ stress protein did not differentiate between the constitutive (HSC 70) and inducible (HSP 70) forms (Welch 1992, Thompson et al. 2001). Differentiation between the constitutive and inducible forms is important because increased synthesis of HSC 70 may act to stabilize proteins at the onset of environmental stress prior to HSP 70 induction. Thompson \& Scordilis (2001) documented elevated levels of HSC 70 in mice 15 min after exercise stress, suggesting this so-called 'constitutive' protein was acting as a 'first defender' following the stress. Therefore, distinguishing between HSC 70 and HSP 70 synthesis in organisms responding to environmental stress provides greater understanding of the mechanism of molecular stress response.
While bleaching events have affected the wider Caribbean since the early 1980s (Lasker et al. 1984, Williams et al. 1987), there were no records of mass bleaching of corals on the Belize (Mesoamerican) barrier reef system before the El Niño-Southern Oscillation (ENSO) episode of 1995 (Burke et al. 1996, McField 1999). Associated with this event, McField (1999) measured over $50 \%$ coral bleaching on the forereef region off Belize. Although most coral colonies recovered within $6 \mathrm{mo}, \sim 10 \%$ experienced at least partial colony mortality. Again, in 1998, the Belize barrier reef was subjected to large-scale disturbances by a severe ENSO event (early August to October 1998) and Hurricane Mitch (October 25 to 31). Aronson et al. (2002a) reported positive $\left(>1^{\circ} \mathrm{C}\right) \mathrm{SST}$ anomalies during autumn 1998 for shelf lagoon and forereef regions off south-central Belize. SSTs exceeded the HotSpot threshold for over $2 \mathrm{wk}$ and reached $+4^{\circ} \mathrm{C}$ in late September. Hurricane Mitch, a category-5 storm on the Saffir/Simpson Hurricane Scale, passed directly over the Bay Islands of Honduras, south of Belize, and introduced enough fresh water to create a freshwater lens 3 $\mathrm{m}$ deep at Carrie Bow Caye in southern Belize (Aronson et al. 2002a). Following these major disturbances, Kramer \& Kramer (2000) reported significant remnant bleaching at forereef sites off Belize 8 mo after the initial bleaching response. In contrast, Mumby (1999) found that although $\sim 80 \%$ of coral colonies on the forereef region ( 8 to $10 \mathrm{~m}$ ) of Glovers Atoll (Belize) appeared to be either fully or partially bleached, these colonies regained their usual coloration in subsequent months.

The 1998 ENSO episode had a particularly strong impact on the shallow shelf lagoonal region off southcentral Belize. Mass bleaching was first observed in this area in early September 1998 (Nemecek 1999). In the Pelican Cayes, nearly 100\% mortality was documented for the spacedominant coral Agaricia tenuifolia at lagoonal reef sites to a depth of $15 \mathrm{~m}$ (Aronson et al. 2000, 2002a, Peckol et al. 2003) following the massive and prolonged bleaching event. Patch reefs also experienced severe and lingering effects from bleaching, particularly for Montastraea annularis, a major reef-building coral (Peckol et al. 2003). A congeneric of A. tenuifolia, A. agaricites, showed lower percentage colony bleaching (Peckol et al. 2001).

Heat stress associated with the 1998 ENSO episode was hypothesized to be responsible for this mass mortality event of Agaricia tenuifolia in the lagoonal reefs of the Pelican Cayes, Belize (Aronson et al. 2000, 2002a). Fitt \& Warner (1995) found that congener A. lamarcki was also sensitive to temperature stress. These lagoonal reefs are steep-sided 'ponds' with limited water flow (Shyka \& Sebens 2000). Due to the enclosed nature and proximity of reefs to freshwater 
incursions during storms, these coral populations may have different stress tolerance levels than populations in forereefs or other locations (Aronson et al. 2000). However, the widespread nature of the bleaching event, including forereef and lagoonal regions, the onset of bleaching prior to Hurricane Mitch and the depth to which coral mortality extended in the Pelican Cayes $(15 \mathrm{~m})$, suggest that prolonged heat stress was the primary cause of the mass coral mortality at this location.

These events led to the present study in which Agaricia agaricites and A. tenuifolia populations were surveyed at lagoonal and forereef sites to document the recovery following these major environmental disturbances. To investigate the effect of heat stress on A. tenuifolia and contrast the effects with a congener, A. agaricites, we measured heat shock protein levels in experimentally heat shocked A. tenuifolia and A. agaricites. Designed to look at a question of physiological responses, this study used immunoblotting for the heat shock cognate protein HSC 70 and inducible heat shock protein HSP 90. Thus, the present study was designed to address the hypothesis that variable HSP expression in A. agaricites and A. tenuifolia may have been important in their differential response to the ENSO warming event of 1998.

\section{MATERIALS AND METHODS}

Study organisms. Agaricia spp. are found throughout the western Atlantic at depths ranging from $\sim 1$ to $>70 \mathrm{~m}$ (Humann \& DeLoach 2002). A. agaricites is a hermaphroditic brooder, creating internally fertilized planula larvae (Fadlallah 1983). These brooded planulae settle close to parent colonies and are able to quickly colonize disturbed reefs. Although no studies have been done on reproductive biology of $A$. tenuifolia, it is also believed to be a brooder as it exhibits similar population dynamics to $A$. agaricites and other brooding corals such as Porites astreoides (Gleason et al. 2001).

Agaricia agaricites and A. tenuifolia have somewhat different but overlapping, biogeographic and depth ranges. A. agaricites is abundant in Florida, the Bahamas and the Caribbean, while A. tenuifolia is common in the western Caribbean and rarer in the eastern part of the basin (Humann \& DeLoach 2002). A. tenuifolia is found across a range of depths (1 to $\sim 30 \mathrm{~m}$ ) and flow regimes in Belize (Sebens et al. 2003). A. agaricites is reported to occur to greater depths than its congener, up to 73 m (Humann \& DeLoach 2002).

Study sites. Our 3 forereef sites (Fig. 1), Tobacco, South Water and Curlew, located near associated cayes, showed well-developed spur and groove forma-

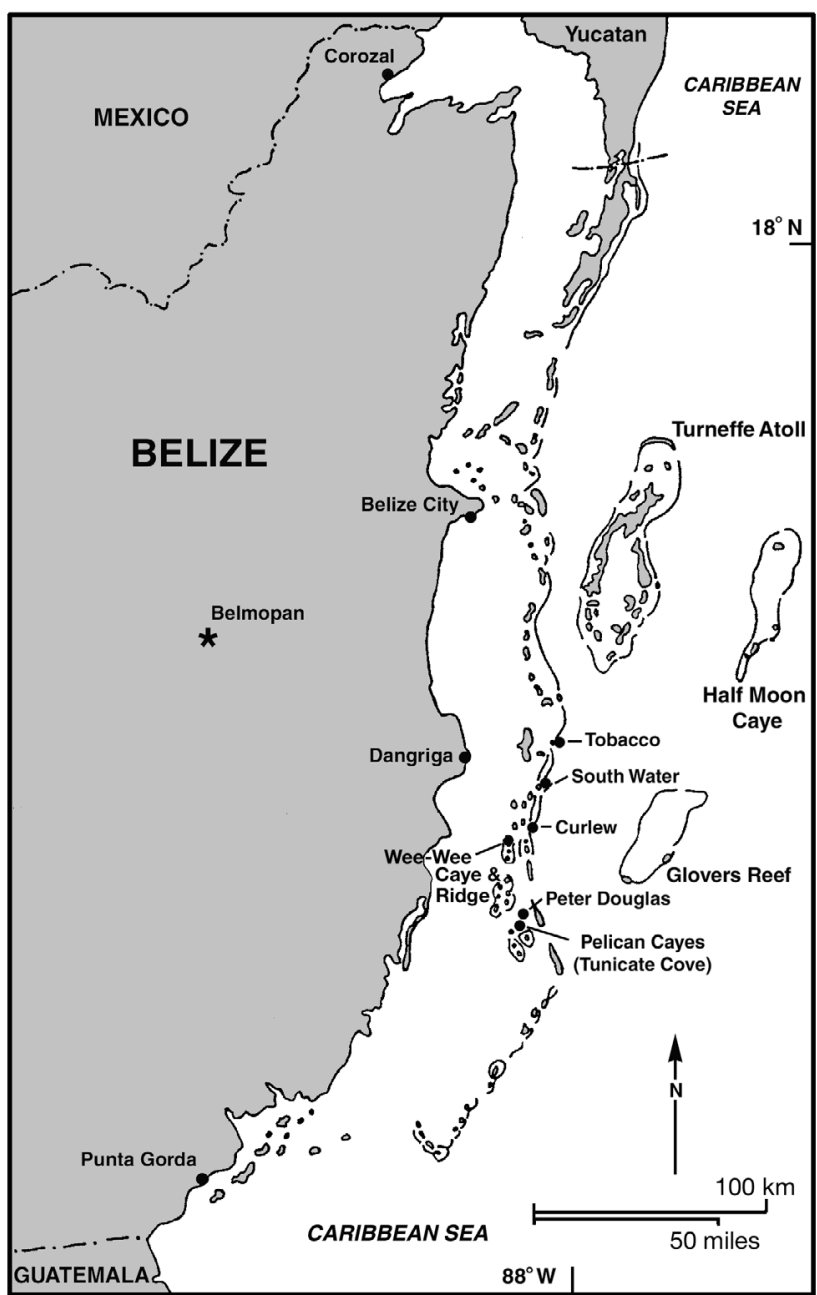

Fig. 1. Belize barrier reef system showing locations of study areas

tions (Peckol et al. 2003). In the south-central shelf lagoon region off Belize, there is a complex network of steep-sided, rhomboidal-shaped shoals and reefs (Aronson \& Precht 1997, Macintyre \& Aronson 1997, Macintyre et al. 2000) (herein referred to as coral reef ridges). The most recent space-dominant corals at these sites included Agaricia agaricites. We selected 3 reef ridge sites for study, Wee Wee, Peter Douglas and Tunicate. Both Wee Wee and Peter Douglas ridges, located off the northern ends of nearby cayes, occurred in relatively well-flushed conditions. Tunicate ridge lies off Cat Caye, one of the Pelican Cayes (Macintyre et al. 2000); this site is under a more restricted flow regime (Shyka \& Sebens 2000, Sebens et al. 2003).

Population characteristics. Population data were collected on corals during January 1999 (Wee Wee ridge and South Water forereef only), June 1999, June 2001 and June 2002 (reef ridges only) using the Atlantic and Gulf Rapid Reef Assessment (AGRRA) 
protocol (Kramer \& Lang 2003, Peckol et al. 2003). $10 \mathrm{~m}$ transect lines ( $\sim 15$ to 22 transects per site, except June $2002, \mathrm{n}=8$ ) were positioned haphazardly on the reef surface parallel to reef growth (8 to $10 \mathrm{~m}$ apart) along the reef ridges and forereef spurs (6 to $15 \mathrm{~m}$ depths). The following information was collected for all corals under the transect lines: genus and species of coral, water depth, maximum colony diameter, percentage of colony dead and percentage of colony bleached/ diseased. We expressed mean partial colony mortality (coral colonies were replicates) for each species at each site. To express percentage live coral cover (overall) and by species (for Agaricia tenuifolia and A. agaricites), we considered each $10 \mathrm{~m}$ transect as a replicate. Because an estimate of $10 \%$ live cover of small versus large coral colonies can represent quite different amounts of live coral cover, we adjusted percentage live cover estimates for colony diameter (percentage of colony alive $\times$ colony diameter). We then summed the adjusted percentage live cover estimates and expressed the sum as a percentage of the $10 \mathrm{~m}$ transect. Reported percentages thus reflect the overall (total) live coral cover, as well as A. tenuifolia and $A$. agaricites live cover, along $10 \mathrm{~m}$ transects.

Percentage cover data were arcsine-transformed prior to use of analysis of variance (ANOVA). We did not include January 1999 or June 2002 assessments in the statistical analyses because of more limited site monitoring or transect number.

Heat shock experiments. Agaricia tenuifolia and A. agaricites were collected at patch reefs in the lagoonal region off Belize in June 2001 to develop techniques used later on experimental corals (see Robbart 2002). Corals used in heat shock experiments were collected at $15 \mathrm{~m}$ on the forereef off Carrie Bow Caye in August 2001 (ambient water temperature = $28^{\circ} \mathrm{C}$ ) and transported to the laboratory in coolers at ambient temperature. Forereef corals were selected because their exposure to elevated summer temperatures was less likely than populations from shallow, patch reef sites, thus reducing the likelihood of preexisting, background levels of HSPs related to thermal acclimation (Fitt et al. 2001) prior to the beginning of the experiment.

Coral fragments (3 to $5 \mathrm{~cm}^{2}$ ) were held in aerated $150 \mathrm{l}$ aquaria at ambient $\left(28^{\circ} \mathrm{C}\right)$ temperatures or heated to $34^{\circ} \mathrm{C}\left(+6^{\circ} \mathrm{C}\right)$. Direct irradiance was blocked with opaque screens. Aquaria were maintained at experimental temperatures for $2 \mathrm{~h}$ and then returned to ambient $\left(28^{\circ} \mathrm{C}\right)$ for $2 \mathrm{~h}$. Corals $(\mathrm{n}=4$, each species and treatment) were then removed and placed in RNALater (Ambion) and frozen at $-20^{\circ} \mathrm{C}$. Coral samples were transported on dry ice.

HSP determination. HSPs were analyzed for coral samples from the heat shock experiment (ambient and $+6^{\circ} \mathrm{C}$ treatments). While some degree of natural biological variation was seen in the initial coral samples (Robbart 2002), HSP levels did not differ significantly between initial samples and the ambient treatment for either Agaricia species. Samples were cleaned of macroscopic epibionts before processing. The area of living coral tissue was measured by flattening aluminum foil in a non-overlapping fashion over the surface of the coral sample (Marsh 1970) and tissue surface area was calculated using an area meter scanner (CID).

Coral fragments ( 1 to $3 \mathrm{~cm}^{2}$ pieces) were heated in Laemmli SDS polyacrylamide gel sample buffer (Laemmli 1970) to separate coral tissue from the calcium carbonate. Tissue aliquots in the sample buffer were precipitated with 3 volumes of $100 \%$ acetone (HPLC grade), mixed and centrifuged for $1 \mathrm{~min}$ at $14000 \times \mathrm{g}$. The pellet was resuspended in cold, distilled $\mathrm{H}_{2} \mathrm{O}$ equal to the original volume and acetoneprecipitated again. After the third resuspension/precipitation the samples were frozen as a pellet at $-80^{\circ} \mathrm{C}$.

Laemmli sample buffer was added to the sample pellet and heated in a boiling water bath for 2 to $3 \mathrm{~min}$ to solubilize protein. Protein concentrations were estimated using the Lowry method (Lowry et al. 1951) using a standard curve of twice recrystallized bovine serum albumin.

Protein extracts were separated by 1-dimensional gel electrophoresis (Laemmli 1970). Samples were loaded onto $12 \%$ (HSC 70) or $10 \%$ (HSP 90) separating gels (5\% stacking gels) using 5,6 or $6.5 \mu \mathrm{g}$ of extract for HSC 70 gels, and 20 or $25 \mu \mathrm{g}$ for HSP 90 gels, along with $0.1 \mu \mathrm{g}$ of HSC 70 standard (SPP-751, StressGen Biotech) and 0.15 or $0.025 \mu \mathrm{g}$ of HSP 90 standard (SPP-770, StressGen Biotech.) (Thompson et al. 2003). Electrophoresis was performed on gels until the dye front was $0.5 \mathrm{~cm}$ from the bottom.

After electrophoresis, gels were transferred onto PVDF membranes (Millipore Corp.) (Towbin et al. 1979) and probed with the appropriate monoclonal antibodies (StressGen Biotech); either rat anti-hamster HSC 70 (1:3000; SPA-815) or rat anti-human HSP 90 monoclonal antibody (1:2000; SPA-840). After incubation overnight in primary antibody at $4{ }^{\circ} \mathrm{C}$, secondary antibody (HSC 70; $1: 3000$ and HSP 90; 1:2000, goat anti-mouse polyvalent-HRP-coupled, A-0412, Sigma) was applied to blots for $2 \mathrm{~h}$ at RT. A monoclonal antibody to plant HSC 70 (SPA-817) was tested to detect zooxanthellar HSPs. Although none were detected (Robbart 2002), the antibody was not specific for dinoflagellate HSPs. Blots were then developed in TMB peroxidase substrate (KLP Laboratories) and dried overnight before being scanned densitometrically for analysis.

Immunoblots were scanned using an HP Scanner at 1200 dpi and Adobe Photoshop software. Protein 


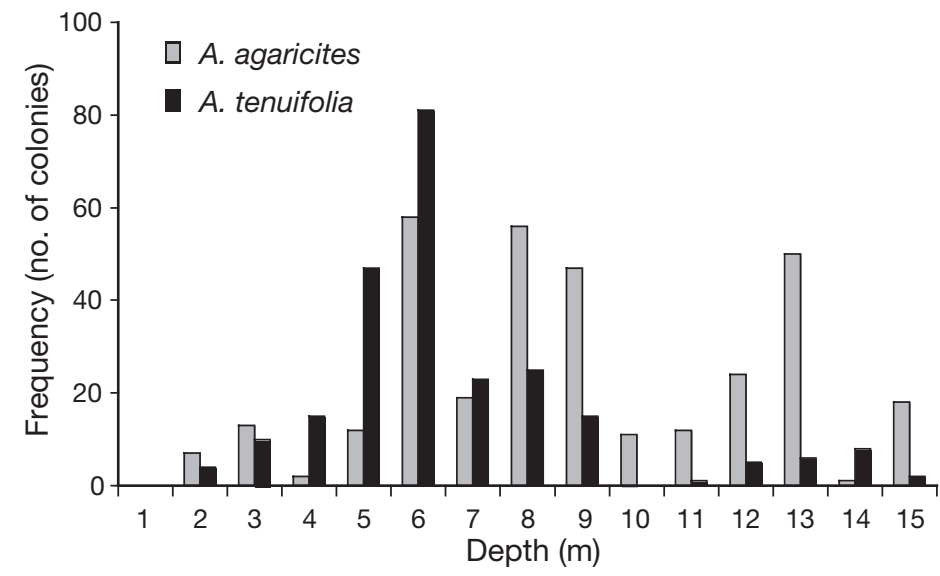

Fig. 2. Agaricia agaricites and A. tenuifolia. Abundance (number of colonies) with depth (m) at Belize forereef sites, Tobacco, South Water, and Curlew. Data combined from June 1999 and 2001 surveys

bands were quantified with Scion Image (Scion Corp.) and areas were analyzed using JMP (SAS Institute).

\section{RESULTS}

\section{Coral abundance, colony mortality and percentage live cover}

Abundance patterns revealed species differences with depth and reef type for colonies of Agaricia agaricites and $A$. tenuifolia at forereef and reef ridge sites (Figs. 2 \& 3). A. tenuifolia was generally more abundant at shallower depths, 4 to $9 \mathrm{~m}$, while $A$. agaricites showed no clear depth preference $\left(\chi^{2}\right.$ analysis: forereef, $\chi^{2}=97.4, \mathrm{p}<0.001$; ridges, $\left.\chi^{2}=31.8, \mathrm{p}<0.001\right)$. Although $A$. agaricites and $A$. tenuifolia showed similar abundances at forereef sites, the latter species was 4 to 5 times more prevalent at the ridge sites.

Total live coral cover (adjusted for colony diameter along $10 \mathrm{~m}$ transect lines) at forereef sites (Fig. 4) was relatively stable between June 1999 and June 2001, and similar among sites (2-way ANOVA, site and time, p > 0.05). During the January 1999 census, coral cover at South Water Caye was somewhat (1-way ANOVA, p > 0.05) reduced (41\%) compared with subsequent sampling periods ( 52\%), perhaps reflecting combined, immediate effects of the thermal anomaly and Hurricane Mitch.

Live coral cover was substantially lower at ridge sites compared with forereef areas (Figs. 4 \& 5). Two-way ANOVA revealed a significant increase in coral cover from June 1999 to June 2001 at ridges $(F=4.45, \mathrm{p}=0.04)$; however, live coral at Tunicate remained lower than the other 2 ridge sites $(F=6.3, \mathrm{p}=0.003)$.
This site difference was still evident during the June 2002 census (Fig. 5).

Percentage live Agaricia cover (adjusted for colony diameter along transect lines) was relatively low at both forereef and ridge sites (Figs. 4 \& 5). During the January 1999 survey at South Water forereef and Wee Wee ridge sites, live cover was $\sim 3$ and $1 \%$ for $A$. tenuifolia and $A$. agaricites, respectively. We found no significant change in percentage live cover between June 1999 and June 2001 for either species (2-way ANOVA, p > 0.05) at forereef sites; however, live cover of $A$. tenuifolia was higher (sites, $F=8.6, p=0.0004$ ) at Curlew than the other forereef sites. At ridge sites, we measured a significant increase in percentage cover for $A$. agaricites (2-way ANOVA, $F=21.4, \mathrm{p}=1.4 \mathrm{E}-05$ ) and A. tenuifolia ( $F=12.2, \mathrm{p}=0.0008)$ from June 1999 to 2001 except at Tunicate, where live cover remained relatively low (for $A$. agaricites: site, $F=3.7, \mathrm{p}=0.03$; A. tenuifolia: site, $F=10.0, \mathrm{p}=0.0001$ ). By the June 2002 census (not included in the statistical analysis because a lower number $[\mathrm{n}=8]$ of transects were measured), $A$ agaricites and $A$. tenuifolia had increased somewhat at Wee Wee and Peter Douglas ridges, but showed low percentage live cover at Tunicate (Fig. 5).

Expressing relative abundance (percentage live Agaricia relative to total live coral cover) of Agaricia spp. revealed distinctive species recovery patterns following the 1998 thermal anomaly and Hurricane Mitch. Except at Curlew where relative abundance remained stable at $\sim 5 \%, A$. agaricites demonstrated 2 - to 3-fold increases in percentage live cover from June 1999 to 2001 (2-way ANOVA: forereefs, $F=6.3$, $\mathrm{p}=0.01$; ridges, $F=21.6, \mathrm{p}=1 \mathrm{E}-05)$. A. tenuifolia showed no significant increases in relative abundance at forereef or ridge sites (2-way ANOVA: time, p > 0.05) during this period.

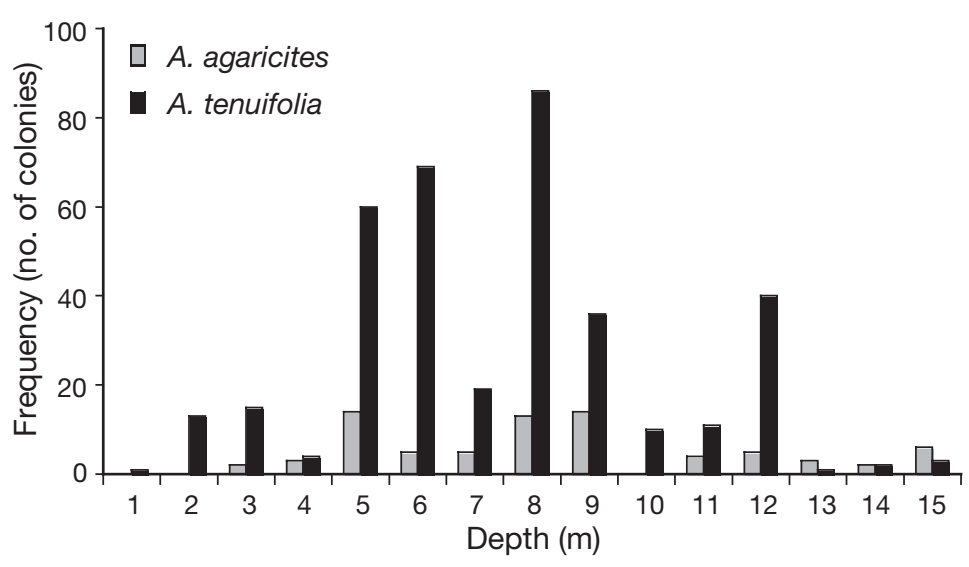

Fig. 3. Agaricia agaricites and A. tenuifolia. Abundance (number of colonies) with depth (m) at Belize reef ridge sites, Wee Wee, Peter Douglas, and Tunicate. Data combined from June 1999 and 2001 surveys 

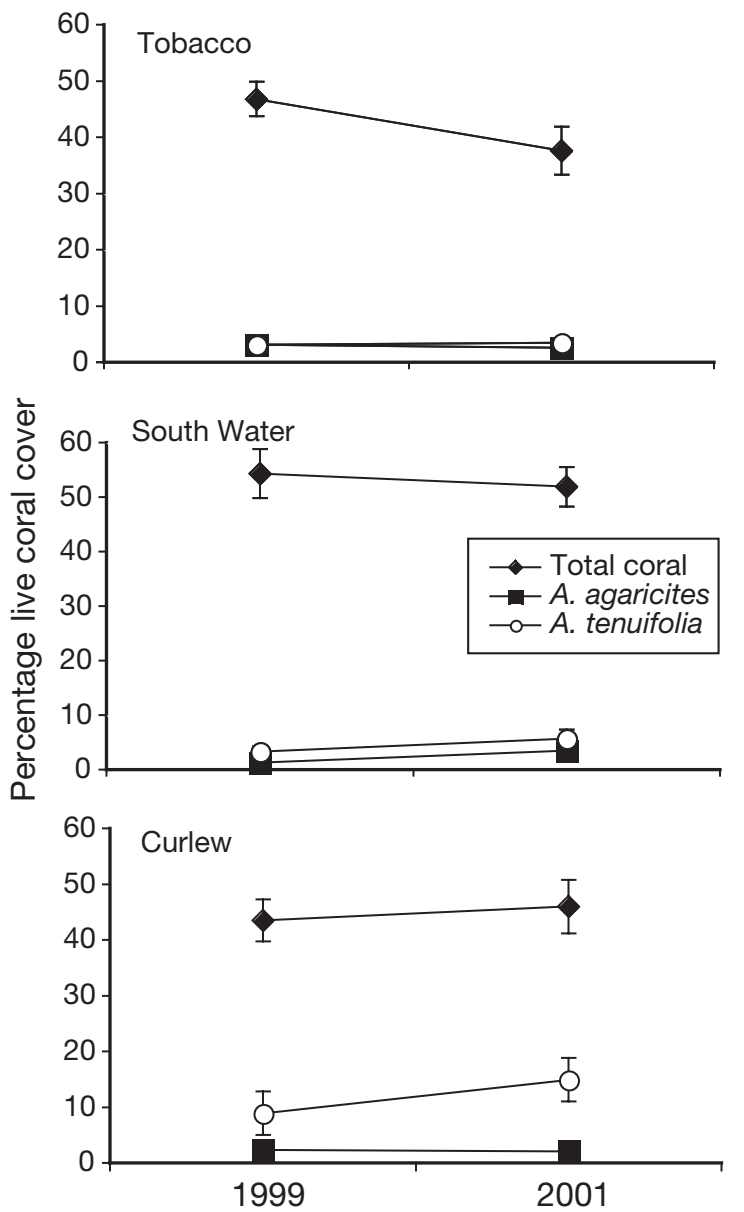

Fig. 4. Mean $( \pm \mathrm{SE})$ percentage live coral cover of all (total) corals, Agaricia agaricites and A. tenuifolia at Belize forereef sites (Tobacco, South Water, and Curlew) during June 1999 and June 2001

Monitoring percentage partial colony mortality provided an additional measure of change for Agaricia agaricites and A. tenuifolia (Table 1). During June 1999, partial colony mortalities were similar for both species at forereef sites, averaging $\sim 30$ and $23 \%$ for $A$. tenuifolia and A. agaricites, respectively, and declining somewhat by 2001 (2-way ANOVA, p > 0.05, both time and species). At reef ridge sites, A tenuifolia showed high partial colony mortality (75 to $95 \%$ ) during 1999 , significantly higher than colony mortality at forereef sites (2-way ANOVA: $F=24.5, \mathrm{p}=0.001)$. Although these values declined by June 2001, mean percentage colony mortality remained $>50 \%$ for this species at 2 ridge sites. Partial colony mortality was much lower for A. agaricites at ridge sites.

The size distribution of Agaricia tenuifolia colonies shifted toward smaller colonies from 1999 to 2001 at reef ridge sites $\left(\chi^{2}=30.2, p=0.0001\right.$, all sites combined) (Fig. 6). For example, all A. tenuifolia colonies at Tunicate ridge were in the smallest size class
$(<20 \mathrm{~cm})$ in 2001. At Wee Wee and Peter Douglas ridges, larger colonies were still in evidence during both 1999 and 2001, suggesting higher colony survival at these sites following the 1998 disturbances.

\section{Heat shock proteins}

Agaricia agaricites showed higher levels of HSC 70 than A. tenuifolia under ambient $\left(28^{\circ} \mathrm{C}\right)$ and heattreated $\left(+6^{\circ} \mathrm{C}\right)$ treatment conditions $(2 \mathrm{~h}$ heat shock, $2 \mathrm{~h}$ ambient) (Figs. $7 \&$ 8). Ambient $A$. agaricites showed significantly $(t=2.6, \mathrm{p}=0.04)$ higher amounts of HSC 70 than $A$. tenuifolia and heat-treated $A$. agaricites showed induced HSC 70 accumulation $(t=$ $4.29, \mathrm{p}=0.005)$.

HSP 90 was detected in Agaricia agaricites (August initial samples and heat shock experiment) but not in A. tenuifolia (Fig. 7). Due to the low sample size ( $\mathrm{n}=1$ to 3), no pattern of expression related to treatment was evident; however, HSP 90 concentrations in A. agaricites were $\sim 5$ to $10 \mu \mathrm{g} \mathrm{cm}^{-2}$ (Robbart 2002).

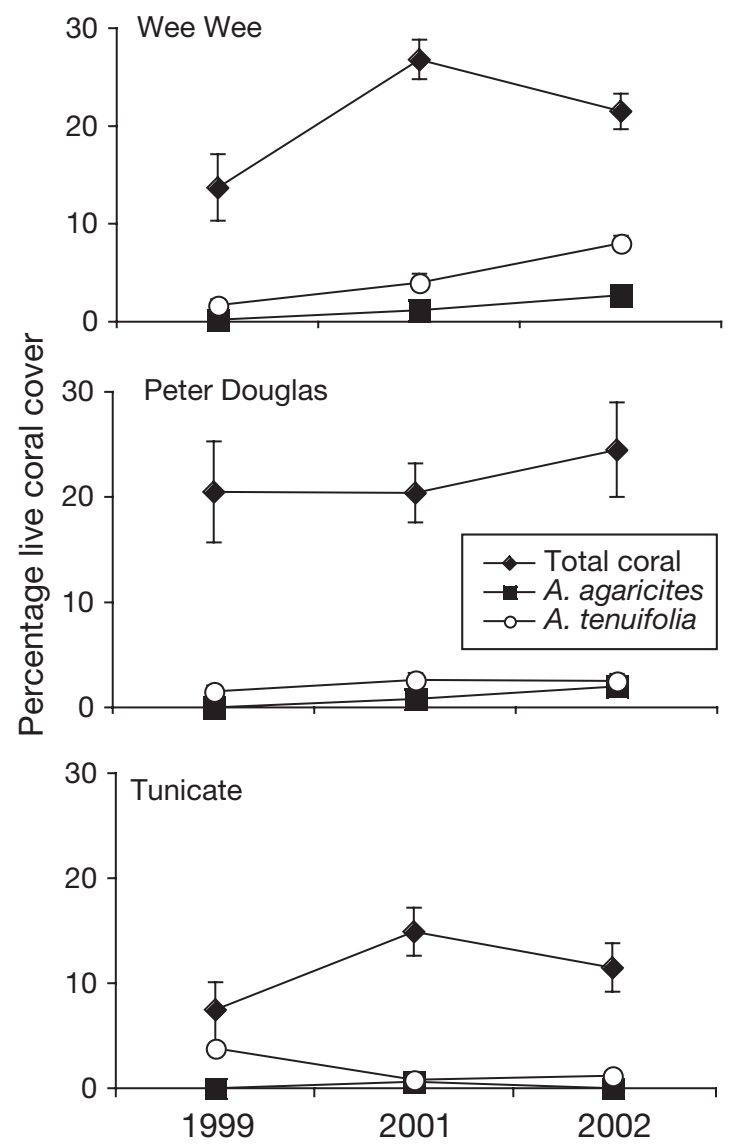

Fig. 5. Mean $( \pm \mathrm{SE})$ percentage live coral cover of all (total) corals, Agaricia agaricites and A. tenuifolia at Belize reef ridge sites (Wee Wee, Peter Douglas, and Tunicate) during June 1999, 2001 and 2002 
Table 1. Mean $( \pm \mathrm{SE})$ percentage partial colony mortality for Agaricia agaricites $(A a)$ and A. tenuifolia (At) from forereef and coral reef ridge sites off Belize during June 1999 and 2001. The number of coral colonies sampled is indicated. ND: no data

\begin{tabular}{|c|c|c|c|c|c|c|c|c|}
\hline \multirow[t]{2}{*}{ Sites } & \multicolumn{4}{|c|}{1999} & \multicolumn{4}{|c|}{2001} \\
\hline & $A a$ & No. of colonies & At & No. of colonies & $A a$ & No. of colonies & At & No. of colonies \\
\hline \multicolumn{9}{|l|}{ Forereef } \\
\hline Tobacco & $11 \pm 5$ & 24 & $20 \pm 7$ & 16 & $10 \pm 3$ & 51 & $10 \pm 3$ & 36 \\
\hline South Water & $41 \pm 10$ & 16 & $24 \pm 6$ & 32 & $9 \pm 3$ & 51 & $9 \pm 3$ & 46 \\
\hline Curlew & $18 \pm 6$ & 21 & $47 \pm 6$ & 36 & $18 \pm 5$ & 34 & $34 \pm 4$ & 73 \\
\hline \multicolumn{9}{|l|}{ Ridges } \\
\hline Wee Wee & $18 \pm 12$ & 9 & $75 \pm 5$ & 69 & $5 \pm 3$ & 33 & $55 \pm 4$ & 98 \\
\hline Peter Douglas & ND & 0 & $90 \pm 3$ & 70 & $12 \pm 5$ & 32 & $28 \pm 5$ & 58 \\
\hline Tunicate & ND & 0 & $95 \pm 2$ & 89 & $0 \pm 0$ & 13 & $71 \pm 6$ & 51 \\
\hline
\end{tabular}
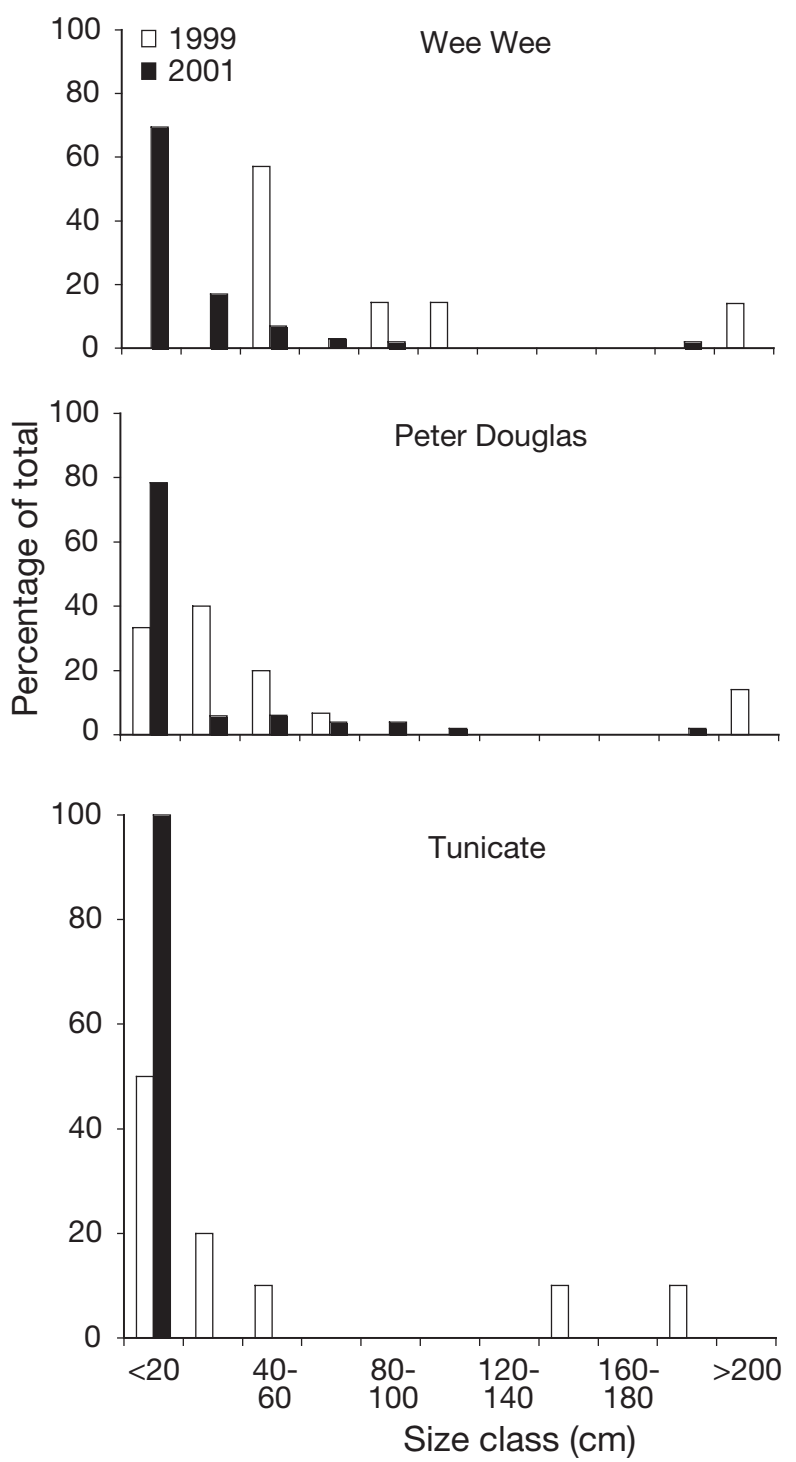

Fig. 6. Agaricia tenuifolia. Size-class distribution of colonies as percentage of total sample at Belize reef ridge sites, Wee Wee, Peter Douglas, and Tunicate, during June 1999 and 2001 surveys
HSP 70, HSP 25, HSP 27 and plant HSC 70 (SPA-812, SPA-801, SPA-800 and SPA-817, respectively, StressGen Biotech) were not detected in samples of either Agaricia agaricites or A. tenuifolia from the August heat shock experiment (Robbart 2002). The absence of plant HSC 70 suggests that zooxanthellar HSC 70 was not present, occurred at undetectable levels in samples or was not possible to detect using the plant HSC antibody.

\section{DISCUSSION}

Immunoblotting results reported here indicate that variable HSP expression in Agaricia agaricites and A. tenuifolia may have been important in their differential response and recovery to the ENSO warming event and the subsequent stressor of Hurricane Mitch on the Belize barrier reef system. Notably, A. agaricites had twice as much HSC 70 as $A$. tenuifolia at ambient temperatures $\left(28^{\circ} \mathrm{C}\right)$ and 6 times as much HSC 70 after heat shock at $+6^{\circ} \mathrm{C}$. Further, no accumulation of HSC 70 was detected in $A$. tenuifolia during $2 \mathrm{~h}$ of heat shock. HSP 90 was only detected in A. agaricites. Aronson et al. (2000) documented nearly $100 \%$ cover of $A$. tenuifolia prior to the thermal anomaly, and subsequently (Aronson et al. 2002a) reported both a higher maximum SST and longer periods of time above the HotSpot threshold for an area near the ridge sites (Channel Caye) compared with a forereef site (Carrie Bow Caye) during the thermal anomaly. Populations of A. agaricites and A. tenuifolia as well as total coral cover, surveyed in the present study at well-flushed forereef sites, showed no significant change in percent live cover between June 1999 and 2001. In addition, a January 1999 survey at South Water Caye soon after the 1998 autumn disturbances suggested only a minor decline in live cover. In contrast, A. tenuifolia, formerly the space dominant coral at ridge sites (Aronson et al. 2002b), suffered major mortality associated with these disturbances (Aron- 


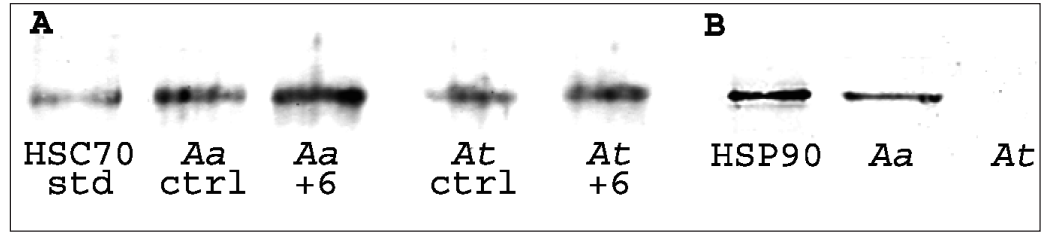

Fig. 7. Representative immunoblots of HSC 70 and HSP 90 blots in Agaricia agaricites (Aa) and A. tenuifolia (At). (A) $100 \mathrm{ng}$ HSC 70 standard, $6 \mu \mathrm{g}$ coral samples either held at ambient temperature $\left(\mathrm{ctrl}, 28^{\circ} \mathrm{C}\right)$ or heat shocked $\left(+6^{\circ} \mathrm{C}\right)$;

(B) $150 \mathrm{ng}$ HSP 90 standard, $25 \mu \mathrm{g}$ coral samples

son et al. 2000, 2002a [see their Fig. 3], Peckol et al. 2003). A. agaricites showed $\sim 18 \%$ partial colony mortality (surveyed at 1 ridge site only), while $A$. tenuifolia exhibited $\sim 75$ to $95 \%$ colony mortality (June 1999 survey). Both Agaricia species showed some population recovery at Peter Douglas and Wee Wee ridge sites but percentage live cover at Tunicate remained extremely low during the June 2002 survey. Population and immunoblotting data together suggest that $A$. tenuifolia was poorly equipped to respond to the intermittent environmental stress characteristic of ENSO events.

Of the 3 ridge sites, Tunicate ridge off Cat Caye had the highest mortality of Agaricia tenuifolia (Aronson et al. 2000, 2002a, Peckol et al. 2003) and negligible recovery. This site is part of a reef system located in the Pelican Cayes: a series of rhomboid shoals, forming enclosed and protected 'ponds' (Macintyre et al. 2000). Shyka \& Sebens (2000) found that reef ridge sites in the Pelican Cayes were low-flow environments ( 1 to $3 \mathrm{~cm} \mathrm{~s}^{-1}$ ) compared with nearby reefs. Flow rates have major effects on several aspects of coral physiology (Sebens 1997), and reduced rates of water exchange would intensify the impact of a thermal stress and increased rainfall from Hurricane Mitch. The continued decline in live $A$. tenuifolia cover at Tunicate ridge following the 1998 ENSO episode was

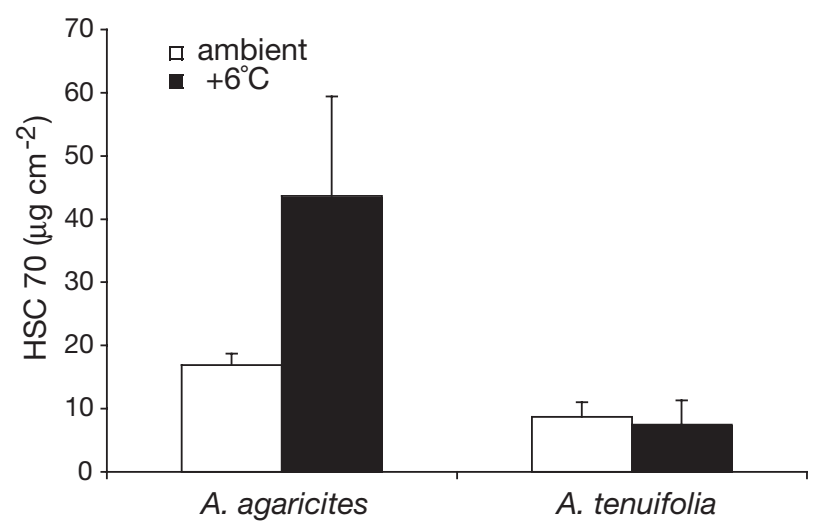

Fig. 8. Agaricia agaricites and A. tenuifolia. Mean $(+\mathrm{SE})$ of HSC expression of coral held under ambient $\left(28^{\circ} \mathrm{C}\right)$ and heated $\left(+6^{\circ} \mathrm{C}\right)$ conditions for $2 \mathrm{~h}$, then returned to ambient temperatures for $2 \mathrm{~h}$ also related to decreased surface area available for coral colonization due to high cover $(>75 \%)$ of the encrusting sponge, Chondrilla cf. nucula Schmidt (Aronson et al. 2002a, Peckol et al. 2003). This shift from coral cover to non-coral cover represents another major transition at this site, similar in scope to the change from the space-dominant Acropora cervicornis to A. tenuifolia following decimation of A. cervicornis to White-band Disease (Aronson \& Precht 1997). Such a shift will likely have significant implications for future recovery (Curran et al. 2004).

The size-distribution data revealed distinctive recovery patterns at the 3 reef ridge sites. At Tunicate ridge, all live Agaricia tenuifolia colonies surveyed during 2002 were $<10 \mathrm{~cm}$ in diameter (with $67 \%$ of the colonies $<5 \mathrm{~cm}$ ) and occurred below $7 \mathrm{~m}$, suggesting that recovery was limited to deeper (cooler) waters and was largely from coral recruits (see also Aronson et al. 2002a). Wee Wee and Peter Douglas ridges had greater numbers of residual colonies that survived the thermal stress as well as new recruits, contributing to the more rapid recovery at these sites. The agariciids are early colonizers of open substrata in reef environments, due to asexual fragmentation and a brooding mode of reproduction that promotes high settlement rates (Hughes \& Jackson 1985, Richmond \& Hunter 1990). Lower encrusting sponge cover on dead $A$. tenuifolia substrata at Wee Wee and Peter Douglas ridges compared with Tunicate (Curran et al. 2004) likely further enhanced coral recovery at these sites.

Agaricia agaricites and A. tenuifolia exposed briefly $(2 \mathrm{~h})$ to heat shock $\left(+6^{\circ} \mathrm{C}\right.$ above ambient) showed differential expression of HSC 70. The experiment was terminated at $4 \mathrm{~h}$, so it is possible that $A$. tenuifolia has a delayed response not evidenced in this study. This is the first HSP research conducted on Agaricia spp.; however, other corals, such as Goniopora djiboutiensis, Montastraea annularis and Acropora grandis showed elevated expression of HSP 70/HSC 70 within 1 to $4 \mathrm{~h}$ of heat shock (Hayes \& King 1995, Fang et al. 1997, Sharp et al. 1997). HSC 70 is known as a constitutive heat shock protein, expressed during normal cellular functioning of cells. Additionally, HSC 70 has been shown to move from its origin in the cytoplasm to the nucleolus (Lindquist \& Craig 1988) and in this location, may play a protective role in stabilizing the proteins necessary to assemble ribosomal subunits. Therefore, HSC 70 may act as a 'first defender' as it is already being produced constitutively.

In the present study, the antibody used was specific for HSC 70 (SPA-815, StressGen Biotech) and no HSP 
70 was detected when probed with an antibody (SPA812, StressGen Biotech) specific for this heat shock protein (Robbart 2002). In some previous heat shock studies conducted on cnidarians where increases in HSP 70 (inducible) were reported (Sharp et al. 1994, 1997, Hayes \& King 1995), the antibody used (Affinity Bioreagents) was not specific for HSP 70 but also recognized HSC 70. Therefore, it would be difficult to determine whether the reported increases in HSPs were due to HSP 70, HSC 70 or a combination of HSP and HSC 70.

HSP 90 was found in 2002 June samples and Augustcollected initial, ambient and $+6^{\circ} \mathrm{C}$ treated Agaricia agaricites but not in $A$. tenuifolia (Robbart 2002). HSP 90 is an abundant chaperone protein in normal and stressed cells, constituting up to $2 \%$ of protein in some organisms (Dierks et al. 1993). Similarly, analysis of HSPs before and after heat shock revealed that Hydra attenuata produced HSP 60, whereas $H$. oligactis did not (Bosch et al. 1988). These researchers suggested that observed declines in natural populations of $H$. oligactis might be attributed to the inability to produce HSPs in response to elevated temperatures that would engender thermotolerance. Thus, A. tenuifolia may not have the ability to synthesize certain HSPs, in this case HSP 90, and was therefore less resistant than A. agaricites to thermal and other environmental stresses.

Plant-specific HSP antibodies were used to investigate possible involvement of zooxanthellar heat shock response but no signal was detected. Notably, Fitt \& Warner (1995) documented contrasting patterns of bleaching in zooxanthellae from Agaricia lamarcki, a coral species which often bleaches during late summer and autumn, compared with zooxanthellae from $A$. agaricites, a coral which bleaches less frequently. Their work suggested that observed patterns of bleaching may be related to varying physiological tolerances of the symbiotic algae. This and other work (Rowan \& Knowlton 1995, Downs et al. 2002) underscore the complexity of the coral-symbiont response to environmental stress.

In the case of fatal coral bleaching, some scleractinian coral species may not be able to produce HSPs to effectively protect cells from degradation and death. The occurrence of SSTs above the HotSpot threshold for prolonged periods of time associated with the 1998 thermal anomaly likely caused the mass mortality of Agaricia tenuifolia at several lagoonal sites in Belize (Aronson et al. 2000, 2002a, Peckol et al. 2003). The present study provides insight into the biochemical mechanism behind such mass mortality events. Although reef corals have been robust through geologic time (Wood 1999), future fluctuations in SSTs associated with intermittent ENSO episodes may drive a dramatic change in the species makeup of tropical, shallow-water reefs.
Acknowledgements. We thank C. Fraga, A. Jugovich, R. Luksic, M. Nestelerode and S. Ristau for field and data-processing assistance; M. Carpenter for boat operation; and $\mathrm{H}$. Thompson for help in developing HSP protocols and HSP statistical analysis. We gratefully acknowledge facilities support at Carrie Bow Caye Marine Field Station (Smithsonian Institution, K. Rützler, Director) and Wee Wee Caye Marine Laboratory (P. and M. Shave, Directors). This research was supported by Blakeslee grants (M.L.R., P.P., S.P.S.), a Culpeper Foundation grant to Smith College (P.P. \& H.A.C.), the Smith College Summer Science Program (J.B.-S), and the B. Elizabeth Horner Fund (M.L.R.). This is contribution \#654 to the Caribbean Coral Reef Ecosystem Program at the National Museum of Natural History, Smithsonian Institution.

\section{LITERATURE CITED}

Aronson RB, Precht WF (1997) Stasis, biological disturbance, and community structure of a Holocene reef. Paleobiology 23:326-346

Aronson RB, Precht WF, Macintyre IG, Murdoch, TJT (2000) Coral bleach-out in Belize. Nature 405:36

Aronson RB, Precht WF, Toscano MA, Koltes KH (2002a) The 1998 bleaching event and its aftermath on a coral reef in Belize. Mar Biol 141:435-447

Aronson RB, Macintyre IG, Precht WF, Wapnick CM, Murdoch TJT (2002b) The expanding scale of species turnover events on coral reefs in Belize. Ecol Monogr 72:233-249

Bosch TCG, Krylow SM, Bode HR, Steele RE (1988) Thermotolerance and synthesis of heat shock proteins: These responses are present in Hydra attenuata but absent in Hydra oligactis. Proc Natl Acad Sci (USA) 85:7927-7931

Branton MA, MacRae TH, Lipschultz F, Wells PG (1999) Identification of a small heat shock/ $\alpha$-crystallin protein in the scleractinian coral Madracis mirabilis (Duch. and Mitch.). Can J Zool 77:675-682

Brown BE (1997) Adaptations of reef corals to physical environmental stress. Adv Mar Biol 31:223-299

Burke CD, Bischoff SJ, Mazzullo SJ, McHenry TM (1996) Coral mortality associated with the 1995 western Caribbean bleaching event, Mexico rocks patch reef complex, Belize. Abstracts with Programs, Geol Soc Am 28:274

Cossins AR, Bowler KB (1987) Temperature biology of animals. Chapman \& Hall, New York

Craig EA (1985) The heat shock response. Crit Rev Biochem 18:239-280

Curran HA, Peckol P, Greenstein BJ, Ristau S, DeYoung S (2004) Shallow-water coral reefs in transition: examples from Belize and the Bahamas. In: Lewis RD, Panuska BC (eds) Proc 11th Symp on the geology of the Bahamas and other carbonate regions. Gerace Research Center, San Salvador, p 13-24

Dierks T, Klappa P, Wiech H, Zimmerman R (1993) The role of molecular chaperones in protein transport into the endoplasmic reticulum. In: Ellis RJ, Laskey RA, Lorimer GH (eds) Molecular chaperones. Chapman \& Hall, Boca Raton, FL, p 79-86

Downs CA, Mueller E, Phillips S, Fauth JE, Woodley CM (2000) A molecular biomarker system for assessing the health of coral (Montastraea faveolata) during heat stress. Mar Biotechnol 2:533-544

Downs CA, Fauth JE, Halas JC, Dustan P, Bermiss J, Woodley CM (2002) Oxidative stress and seasonal coral bleaching. Free Radical Bio Med 33:533-543

Eakin CM (1996) Where have all the carbonates gone? A model comparison of calcium carbonate budgets before 
and after the 1982-83 El Niño at Uva Island in the eastern Pacific. Coral Reefs 15:109-119

Fadlallah YH (1983) Sexual reproduction, development and larval biology in scleractinian corals: a review. Coral Reefs 2:129-150

Fang LS, Huang SP, Lin KL (1997) High temperature induces the synthesis of heat shock proteins and the elevation of intracellular calcium in the coral Acropora grandis. Coral Reefs 16:127-131

Fitt WK, Warner ME (1995) Bleaching patterns of four species of Caribbean reef corals. Biol Bull 189:298-307

Fitt WK, Brown BE, Warner ME, Dunne RP (2001) Coral bleaching: interpretation of thermal tolerance limits and thermal thresholds in tropical corals. Coral Reefs 20:51-65

Gleason DF, Brazeau DA, Munfus D (2001) Can self-fertilizing coral species be used to enhance restoration of Caribbean reefs? Bull Mar Sci 69:933-943

Glynn PW (1993) Coral reef bleaching: ecological perspectives. Coral Reefs 12:1-17

Hayes RL, King CM (1995) Induction of a 70-kDa heat shock protein in scleractinian corals by elevated temperature: significance for coral bleaching. Mol Mar Biol Biotechnol $4: 36-42$

Hughes TP, Jackson JBC (1985) Population dynamics and life history of foliaceous corals. Ecol Monogr 55:141-166

Humann P, DeLoach N (2002) Reef coral identification. New World Publications, Jacksonville, FL

Jokiel PL, Coles SL (1977) Effects of temperature on the mortality and growth of Hawaiian reef corals. Mar Biol 43: 201-208

Kramer PA, Kramer PR (2000) Ecological status of the Mesoamerican Barrier Reef System: Impacts of Hurricane Mitch and 1998 coral bleaching. Final Report to the World Bank, RSMAS, University of Miami, FL

Kramer PR, Lang JC (2003) The Atlantic and Gulf rapid reef assessment protocols: former version 2.2. Atoll Res Bull 496:611-618

Laemmli UK (1970) Cleavage of structural proteins during the assembly of the head of bacteriophage T4. Nature 227: 680-685

Lasker H, Peters E, Coffroth MA (1984) Bleaching of reef coelenterates in the San Blas Islands, Panama. Coral Reefs 3:183-190

Laszlo A (1992) The thermoresistant state: protection from initial damage or better repair? Exp Cell Res 202:519-531

Lesser MP, Stochaj WR, Tapley DW, Shick JM (1990) Bleaching in coral reef anthozoans: effects of irradiance, ultraviolet radiation, and temperature on the activities of protective enzymes against active oxygen. Coral Reefs 8: 225-232

Lindquist S, Craig EA (1988) The heat shock proteins. Ann Rev Gen 22:631-677

Lowry OH, Rosenberg NJ, Farr AL, Randall RJ (1951) Protein measurement with the Folin phenol reagent J Biol Chem 193:265-275

Macintyre IG, Aronson RB (1997) Field guidebook to the reefs of Belize. In: Proc 8th Int Coral Reef Symp Panama, 1: 203-222

Macintyre IG, Precht WF, Aronson RB (2000) Origins of the Pelican Cays Ponds, Belize. Atoll Res Bull 466:1-11

Marsh JA (1970) Primary productivity of reef-building calcareous algae. Ecology 51:255-263

McField M (1999) Coral response during and after mass bleaching in Belize. Bull Mar Sci 64:155-172

Mumby PJ (1999) Bleaching and hurricane disturbances to populations of coral recruits in Belize. Mar Ecol Prog Ser 190:27-35

Nemecek S (1999) Whiteout. Sci Am 280:30-32

Peckol P, Curran HA, Robbart M, Greenstein BJ (2001) Resilience and recovery of coral reefs from large-scale disturbances: contrasting patterns for San Salvador Island, Bahamas and Belize. In: Greenstein BJ, Carney CK (eds) Proc 10th Symp on the Geol of the Bahamas and other carbonate regions, Gerace Research Center, p 129-141

Peckol P, Curran HA, Floyd E, Robbart M, Greenstein BJ, Buckman K (2003) Assessment of the condition of forereef and backreef sites of northern and south-central Belize, including recovery from bleaching and hurricane disturbances (stony corals, algae and fish). Atoll Res Bull 496:146-171

Richmond RH, Hunter CL (1990) Reproduction and recruitment of corals: comparisons among the Caribbean, the Tropical Pacific, and the Red Sea. Mar Ecol Prog Ser 60: 185-203

Robbart M (2002) Population dynamics and differential heat shock protein expression in two Caribbean scleractinian corals, Agaricia agaricites and A. tenuifolia. MA thesis, Smith College, Northampton, MA

Rowan R, Knowlton N (1995) Intraspecific diversity and ecological zonation in coral-algal symbiosis. Proc Natl Acad Sci 92:2850-2853

Sebens KP (1997) Adaptive responses to water flow: morphology, energetics, and distribution of reef corals. In: Proc 8th Coral Reef Symp 2:1053-1058

Sebens KP, Helmuth B, Carrington E, Agius B (2003) Effects of water flow on growth and energetics of the scleractinian coral Agaricia tenuifolia in Belize. Coral Reefs 22:35-47

Sharp VA, Miller D, Bythell JC, Brown BE (1994) Expression of low molecular weight HSP 70 related polypeptides from the symbiotic sea anemone Anemonia viridis Forskall in response to heat shock. J Exp Mar Biol Ecol 179:179-193

Sharp VA, Brown BE, Miller D (1997) Heat shock protein expression (HSP 70) expression in the tropical reef coral Goniopora djiboutiensis. J Therm Biol 22:11-19

Shyka TA, Sebens KP (2000) Community structure, water column nutrients, and water flow in two Pelican Cays Ponds, Belize. Atoll Res Bull 471:107-125

Thompson HS, Scordilis S (2001) Downhill running elicits distinct but similar protein and mRNA expression patterns of HSP 25, HSC 70 and HSP 70. Faseb J 15:A417

Thompson HS, Scordilis SP, Clarkson PM, Lohrer WA (2001) A single bout of eccentric exercise increases HSP 27 and HSC/HSP 70 in human skeletal muscle. Acta Physiol Scand 171:187-194

Thompson HS, Maynard EB, Morales ER, Scordilis SP (2003) Exercise-induced HSP 27, HSP 70 and MAPK responses in human skeletal muscle. Acta Physiol Scand 178:61-72

Towbin H, Staehelin T, Gordon J (1979) Electrophoretic transfer of proteins from polyacrylamide gels to nitrocellulose sheets: procedure and some applications. Proc Natl Acad Sci 76:4350-4354

Welch WJ (1992) Mammalian stress response: cell physiology, structure/function of stress proteins, and implications for medicine and disease. Physiol Rev 72:1063-1081

Wilkinson CR (2000) Executive summary. In: Wilkinson C (ed) Status of the coral reefs of the world: 2000. Australian Institute of Marine Science, Cape Ferguson and Dampier, p 7-17

Williams E, Goenaga C, Vicente V (1987) Mass bleaching on Atlantic coral reefs. Science 238:877-878

Wood R (1999) Reef evolution. Oxford University Press, New York

Submitted: July 8, 2003; Accepted: August 10, 2004

Proofs received from author(s): November 5, 2004 